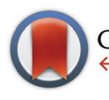

CrossMark \& click for updates

Cite this: Food Funct., 2016, 7, 2016

\title{
In vitro bioaccessibility of proteins and lipids of pH-shift processed Nannochloropsis oculata microalga
}

\author{
L R. Cavonius, * E. Albers and I. Undeland
}

The $\mathrm{pH}$-shift process fractionates biomass into soluble proteins and insoluble fractions, followed by precipitation and recovery of the solubilized proteins. Nannochloropsis oculata in seawater was subjected to the $\mathrm{pH}$-shift process, followed by digestion of various intermediates and product fractions of the process, using the Infogest in vitro digestion model (Minekus et al., 2014) with added gastric lipase. As measures for protein and lipid accessibility, degrees of protein hydrolysis and fatty acid liberation were assessed post-digestion and compared to the amounts of peptide bonds and total fatty acids present in the raw materials. Results showed that neither proteins nor lipids of intact Nannochloropsis cells were accessible to the mammalian digestive enzymes used in the digestion model. Cell disruption, and to a lesser extent, further $\mathrm{pH}$-shift processing with protein solubilisation at $\mathrm{pH} 7$ or $\mathrm{pH} 10$, increased the accessibility of lipids. For proteins, differences amongst the $\mathrm{pH}$-shift processed materials were non-significant, though pre-freezing the product prior to digestion increased the accessibility from $32 \%$ to $47 \%$. For fatty acids, $\mathrm{pH}$-shift process-products gave rise to $43 \%$ to $52 \%$ lipolysis, with higher lipolysis for products solubilised at $\mathrm{pH} 10$ as opposed to $\mathrm{pH}$ 7. Our results indicate the importance of processing to produce an algal product that has beneficial nutritional properties when applied as food or feed.

Received 18th September 2015 Accepted 14th March 2016

DOI: $10.1039 / c 5 f o 01144 b$

www.rsc.org/foodfunction a refined protein fraction. The refined protein can show an altered technical functionality, e.g. gelling properties, since proteins are partially denatured in the process and may take on non-native conformations when re-folding. ${ }^{4,5}$ In a first application of the $\mathrm{pH}$-shift process to $\mathrm{N}$. oculata in seawater, the nutritional composition was studied before and after processing: a modest reduction in the ash content was observed, while the concentration of proteins, lipids and carbohydrates remained stable or increased slightly. ${ }^{3}$ The study also included a comparison of protein solubilisation at either the algae suspension's native $\mathrm{pH} 7$ or $\mathrm{pH}$ 10. Although the compositions of the products were similar, it cannot be excluded that the solubilisation $\mathrm{pH}$ impacted the degree of protein unfolding or refolding and thereby altered the technical functional properties of the product, as well as the digestibility. To the best of our knowledge, the impact of pH-shift processing on algal digestibility has not been studied earlier.

The digestibility or accessibility of a food matrix is a measure of how much of the food component is available for uptake. Generally, microagal in vitro digestion studies have focused on proteins, ${ }^{6-11}$ though lipid-soluble compounds have also been assessed. ${ }^{12}$ Using sundry different methods to assess the digestibility of proteins and lipid-soluble compounds, these studies' conclusions can be summarised as follows: the protein digestibility of Scenedesmus obliquus was 
increased by cell disruption (bead-milling); ${ }^{6}$ the protein digestibility of Spirulina platensis was greater when the algae are fresh as opposed to dried (either freeze-dried or sundried); ${ }^{7}$ Chlorella vulgaris algae subjected to mechanical disruption, drying, and ethanol-extraction were more susceptible to digestion by pancreatin than disrupted, dried, non-extracted algae; ${ }^{9}$ treatment of dried Galdieria sulphuraria with a carbohydrase cocktail increased the protein digestibility $;^{10}$ accessibility of $\beta$-carotene, lycopene and $\alpha$-tocopherol from Nannochloropsis oculata and Chaetoceros calcitrans increased when the lipophilic compounds were extracted into specific solvents. ${ }^{12}$

Nannochloropsis has been subjected to both in vitro digestion and a feeding trial. ${ }^{11,13}$ In the in vitro digestion, both whole Nannochloropsis granulata and lipid-extracted $N$. granulata were compared, with low protein digestibility $(15-28 \%)$ reported for the whole algae, while digestibility improved somewhat for lipid-extracted algae. ${ }^{11} \mathrm{~A}$ feeding trial on mink with Nannochloropsis oceanica demonstrated that the apparent crude-protein and lipid digestibility decreased as increasing amounts of Nannochloropsis were added to the mink chow. ${ }^{13}$ The authors reached the conclusion that cell disruption would likely increase the protein and lipid digestibility of Nannochloropsis. ${ }^{13}$ A recent publication offers an explanation for the poor digestibility of whole Nannochloropsis cells: the cell wall of Nannochloropsis is composed primarily of cellulose, surrounded by an outer layer of algaenan, which could be expected to block enzymes from acting on the cell. ${ }^{14}$

In the various aforementioned digestibility studies, not only the analysed end-points are different, but the applied in vitro digestion protocols also differ. This makes results from different in vitro digestion studies difficult to compare. The Infogest consortium (encompassing over 250 scientists from 32 different countries, coordinated by the French National Institute for Agricultural Research) has been working towards harmonising digestion models, which has resulted in published guidelines (Minekus et al., 2014). ${ }^{15}$ The published guide, however, omits gastric lipases, as these were not commercially available at the time of publication, even though it is established that gastric lipases have a significant impact on lipolysis. ${ }^{15,16}$ Recently, rabbit gastric lipase has become purchasable. We believe that the protocol suggested by Minekus et al., 2014, ${ }^{15}$ but with a minor change to include gastric lipase according to Capolino et al., 2011, ${ }^{17}$ would provide data closer to an in vivo scenario, yet comparable to other in vitro studies.

Heat-treatment of food is common, either as part of the pre-consumer processing or immediately prior to consumption. Heat-treatment can change the nutritive value of a food, e.g. by protein denaturation or the Maillard reaction. ${ }^{18}$ Nostoc commune has been subjected to mild cell disruption and heattreatment with dry and wet heat at 100 and $120^{\circ} \mathrm{C}$, resulting in no statistically significant difference in protein digestibility compared to non-heated Nostoc commune. ${ }^{8}$ Since Nostoc commune is a cyanobacterium while Nannochloropsis oculata is a eukaryote, it is conceivable that the protein and lipid digestibility of Nannochloropsis is affected differently by cell disruption and heating.
The aim of this paper was to investigate the accessibility of proteins and lipids of $\mathrm{pH}$-shift processed $N$. oculata using enzyme levels of the standardised Infogest in vitro digestion model with added gastric lipase. ${ }^{15,17}$ To answer how the process per se affects accessibility and also what difference a heat-treatment makes, the following materials were included in the comparison: whole-algae-in-seawater (ALG), disrupted algae (LYS), and products of the pH-shift process with solubilisation at $\mathrm{pH} 7$ or 10 with and without heat-treatment $[\mathrm{P}(7) \mathrm{H}$, $\mathrm{P}(10) \mathrm{H}, \mathrm{P}(7), \mathrm{P}(10)]$. Responses analysed were (i) the relative amount of broken peptide bonds (degree of protein hydrolysis, DH) and (ii) the relative amount of liberated free fatty acids (FFA).

\section{Materials and methods}

\section{pH-Shift processing of Nannochloropsis}

The product of Necton, microalgae Nannochloropsis oculata "Phytobloom ice" for aquaculture, was purchased in March 2012, delivered as a frozen wet paste ( $c a .30 \%$ dry weight) and stored at $-80{ }^{\circ} \mathrm{C}$. Seawater was obtained from the marine research station of the Sven Lovén Centre for Marine Sciences at Tjärnö, Sweden, and was filtered through a $0.22 \mu \mathrm{m}$ membrane and then autoclaved. The materials ALG, LYS, P(7), $\mathrm{P}(10), \mathrm{P}(7) \mathrm{H}$ and $\mathrm{P}(10) \mathrm{H}$ were snap-frozen immediately after production, with one protein of $\mathrm{P}(7)$ remaining non-frozen: $\mathrm{P}(7)$ NF. Fig. 1 shows an overview of the algae-containing materials prepared for later in vitro digestion. The $\mathrm{pH}$-shift process was carried out on ice, according to the process reported previously: ${ }^{3}$ one part of wet microalgal paste was thawed and mixed with four parts seawater. Algae in seawater were shaken until dissociation to mimic a microalgal culture which had been harvested by dewatering to $c a .10 \%$ dry weight. An aliquot of ALG was snap-frozen for later digestion

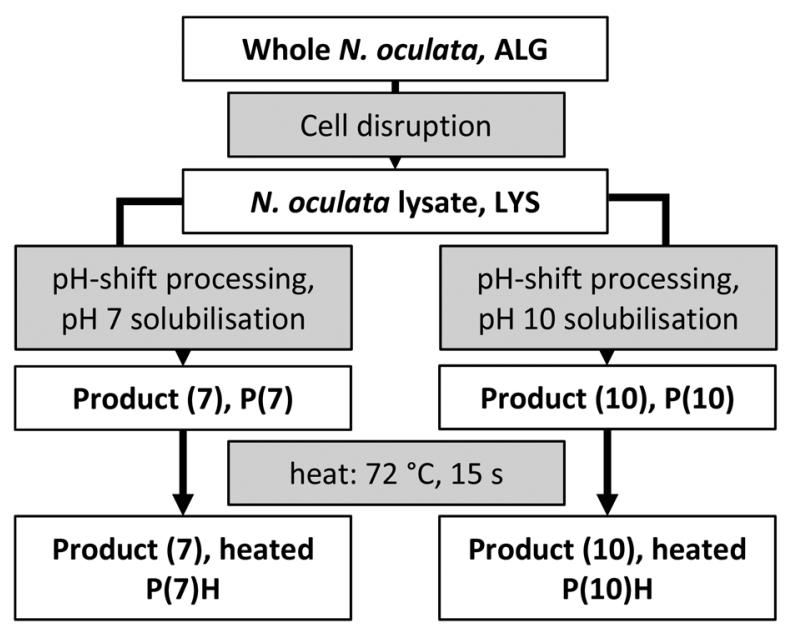

Fig. 1 Production scheme for the algal materials used in in vitro digestion. The materials ALG, LYS, $P(7), P(10), P(7) H$ and $P(10) H$ were snapfrozen immediately after production, with one portion of $P(7)$ remaining non-frozen: $\mathrm{P}(7) \mathrm{NF}$. 
and analysis by plunging the containing tube into a slurry of $95 \%$ ethanol and dry ice at ca. $-78{ }^{\circ} \mathrm{C}$; after freezing, tubes were stored at $-80{ }^{\circ} \mathrm{C}$ until use. The remaining algae suspension $(20 \mathrm{ml})$ was transferred to a $50 \mathrm{ml}$ Falcon tube containing $10 \mathrm{ml}$ of glass beads (212-300 $\mu \mathrm{m}$, Sigma, acid-washed before use). Algae were disrupted by shaking the tube at $30 \mathrm{~s}^{-1}$ for $3 \times 200 \mathrm{~s}$ in a Retsch MM400 (with adapters for $50 \mathrm{ml}$ Falcon tubes); the tubes were cooled in ice between cycles. Near-complete disruption was confirmed by phase-contrast microscopy (Axiostar plus, Carl Zeiss, Germany at 400× magnification with an A-plan 40×/0.65 objective, $\infty / 0.17$, and appropriate phase plate). Beads were removed by passing the suspension over a $100 \mu \mathrm{m}$ mesh and LYS was collected on ice. An aliquot of LYS was snap-frozen for later digestion and analysis. The $\mathrm{pH}$ was measured with a Radiometer analytical PHM210 pH meter with a Hamilton double pore electrode (Christian Berner, Sweden). The remaining LYS was split into two streams, one in which the solubilisation $\mathrm{pH}$ was the native $\mathrm{pH}$ of the lysate ( $\mathrm{pH} 7)$; in the other stream, the $\mathrm{pH}$ was adjusted to 10 with $1.0 \mathrm{M} \mathrm{NaOH}$ (prepared from $\mathrm{NaOH}$ pellets, Scharlau, purity $\geq 98.5 \%$, and ultrapure water). Suspensions were centrifuged $\left(4{ }^{\circ} \mathrm{C}, 4000 \mathrm{~g}, 10 \mathrm{~min}\right.$; Heraeus multifuge $1 \mathrm{~S}-\mathrm{R}$ with a swingingbucket rotor) and the supernatants containing the majority of the proteins and lipids, ${ }^{3}$ were recovered. The supernatants were precipitated by adjusting the $\mathrm{pH}$ to 3 with $1.0 \mathrm{M} \mathrm{HCl}$ (prepared from $37 \% \mathrm{HCl}$, Scharlau, ACS). The suspensions were centrifuged as above, and the pellets were neutralized to $\mathrm{pH} 7$ with $\mathrm{NaOH}$, yielding a product of both the $\mathrm{pH}$ 7-process $[\mathrm{P}(7)]$ and $\mathrm{pH}$ 10-process $[\mathrm{P}(10)]$. Aliquots of $\mathrm{P}(7)$ and $\mathrm{P}(10)$ were snap-frozen for later digestion and analysis. Some $\mathrm{P}(7)$ was kept liquid $[\mathrm{P}(7) \mathrm{NF}]$ and was digested on the same day of the $\mathrm{pH}$-shift process to elucidate the effect of snap-freezing. The remaining product was filled into $15 \mathrm{ml}$ test tubes (roundbottom, polypropylene, TPP, Switzerland) and placed into the snug-fitting bore of a heating block (Grant QBH2, Cambridge, United Kingdom) at $95{ }^{\circ} \mathrm{C}$ for $360 \mathrm{~s}$, by which time the core temperature was at least $72{ }^{\circ} \mathrm{C}$ for not less than $15 \mathrm{~s}$, conditions typical of a high-temperature short-time pasteurization. ${ }^{19}$ Aliquots of both heat-treated products $[\mathrm{P}(7) \mathrm{H}$ and $\mathrm{P}(10) \mathrm{H}]$ were snap-frozen for later digestion and analysis.

\section{In vitro digestion}

The digestion followed the protocol recommended by Minekus et al., $2014^{15}$ with a modification to include gastric lipase as recommended by Capolino et al., 2011. ${ }^{17}$ The modification involved that the gastric step (120 min at pH 3 with pepsin, in the original protocol) was altered to a first step at $\mathrm{pH} 5.5$ with rabbit gastric lipase for $30 \mathrm{~min}$, followed by $\mathrm{pH} 3$ with pepsin for $90 \mathrm{~min}$; a more detailed description of raw materials, digestion enzymes, digestion fluids and bile acid follows below.

Enzyme activities were measured according to Minekus et al., 2014: ${ }^{15} \alpha$-amylase from porcine pancreas (Sigma, type VI-B) was $13 \mathrm{U} \mathrm{mg}^{-1}$, pepsin from porcine stomach mucosa (Sigma) was $900 \mathrm{U} \mathrm{mg}^{-1}$, and pancreatin from porcine pancreas (Sigma, $4 \times$ USP) was $3.6 \mathrm{U} \mathrm{mg}^{-1}$ (based on lipase activity). Rabbit gastric lipase was purchased from Germe,
Marseille, France and according to its specification was $70 \mathrm{U} \mathrm{mg}^{-1}$. The total bile acids of porcine bile extract (Sigma) were determined according to Minekus et al., $2014^{15}$ to be $1.4 \mu \mathrm{mol} \mathrm{mg}{ }^{-1}$. The composition of simulated salivary fluid, simulated gastric fluid and simulated intestinal fluid is described by Minekus et al. (2014). ${ }^{15}$ The $\mathrm{Ca}^{2+}$-content of ALG was determined to be $9 \mathrm{mmol} \mathrm{l}^{-1}$ by high-pressure ion chromatography as reported in our previous work on $\mathrm{pH}$-shift processing, using the same method as that for $\mathrm{Na}^{+}$-quantification. ${ }^{3}$ Since the $\mathrm{Ca}^{2+}$ concentration was well in excess of the concentration recommended by Minekus et al., 2014, ${ }^{15}$ no $\mathrm{Ca}^{2+}$ was added in the digestion.

An overview of the digestion is given in Fig. 2. For samples containing Nannochloropsis, $2.5 \pm 0.5 \mathrm{~g}$ of the material was weighed in $50 \mathrm{ml}$ Falcon tubes (tapered bottom, polypropylene, TPP, Switzerland); for seawater blank (SW), $2.5 \mathrm{ml}$ seawater was used and for the DH-control casein (CAS), $75 \mathrm{mg}$ casein [from bovine milk, purchased from Sigma, corresponding to the amount of protein present in $2.5 \mathrm{~g} \mathrm{P}(7)$ ], was mixed with $2.43 \mathrm{ml}$ seawater. For the oral step, $1.75 \mathrm{ml} \mathrm{simu-}$ lated salivary fluid at $37{ }^{\circ} \mathrm{C}$ was added and the tube was vortexed briefly to homogenise. Next, amylase solution (1500 $\mathrm{U} \mathrm{ml}^{-1}$, in simulated salivary fluid, $0.25 \mathrm{ml}$ at $37^{\circ} \mathrm{C}$ ) and ultrapure water $\left(0.5 \mathrm{ml}\right.$ at $\left.37^{\circ} \mathrm{C}\right)$ were added and the tube was vortexed to homogenise the content. Thereafter, the tube was shaken in an upright position, at $200 \mathrm{rpm}$ at $37^{\circ} \mathrm{C}$ for $2 \mathrm{~min}$ (water bath SW22, from Julabo, Seelbach, Germany). For the first gastric step, rabbit gastric lipase solution $(1.5 \mathrm{ml}$, $102 \mathrm{U} \mathrm{ml}^{-1}$ in simulated gastric fluid) and simulated gastric fluid $(1.7 \mathrm{ml})$ were added and the $\mathrm{pH}$ was adjusted to 5.5 (using $1.0 \mathrm{M} \mathrm{HCl}$ ). The tube was shaken as above for $30 \mathrm{~min}$, and the $\mathrm{pH}$ was kept between 5.3 and 5.7 with $\mathrm{HCl}$. For the second gastric step, pepsin solution $\left(25000 \mathrm{U} \mathrm{ml}^{-1}\right.$ in simulated gastric fluid, $0.8 \mathrm{ml}$ ), was added and the $\mathrm{pH}$ was adjusted to 3.0 (with $\mathrm{HCl}$ ). The volume of the mixture was adjusted to $10 \mathrm{ml}$ with ultrapure water and the tube was shaken as above for $90 \mathrm{~min}$, with addition of $\mathrm{HCl}$ as necessary to keep the $\mathrm{pH}$ between 2.9 and 3.1. For the intestinal step, simulated intestinal fluid $(5.5 \mathrm{ml})$ was added. Pancreatin solution $\left(800 \mathrm{U} \mathrm{ml}^{-1}\right.$, in simulated intestinal fluid, $2.5 \mathrm{ml}$ ) was added, followed by bile solution (160 mmol bile acids per 1 , in ultrapure water, $1.25 \mathrm{ml})$. NaOH $(1.0 \mathrm{M})$ was added to adjust the $\mathrm{pH}$ to 7.0. Ultrapure water was added to bring the total volume to $20 \mathrm{ml}$. The tube was shaken as above for $120 \mathrm{~min}$, with addition of $\mathrm{HCl}$ as necessary to keep the $\mathrm{pH}$ between 7.0 and 7.2. Aliquots for measuring the degree of protein hydrolysis and fatty acid extraction were withdrawn and snap-frozen by plunging the tubes into a slurry of $95 \%$ ethanol and dry ice at ca. $-78{ }^{\circ} \mathrm{C}$; after freezing, the tubes were stored at $-80^{\circ} \mathrm{C}$ until analysis.

\section{Compositional analysis of $\mathrm{pH}$-shift process products}

The $\mathrm{pH}$-shift process reported above is identical to the one we previously reported, carried out on the same microalgal paste. ${ }^{3}$ In the mentioned study, the composition of LYS, $\mathrm{P}(7)$ and $\mathrm{P}(10)$ was reported, but as information to the reader, we include it in Table 1. In brief, the water content was measured 


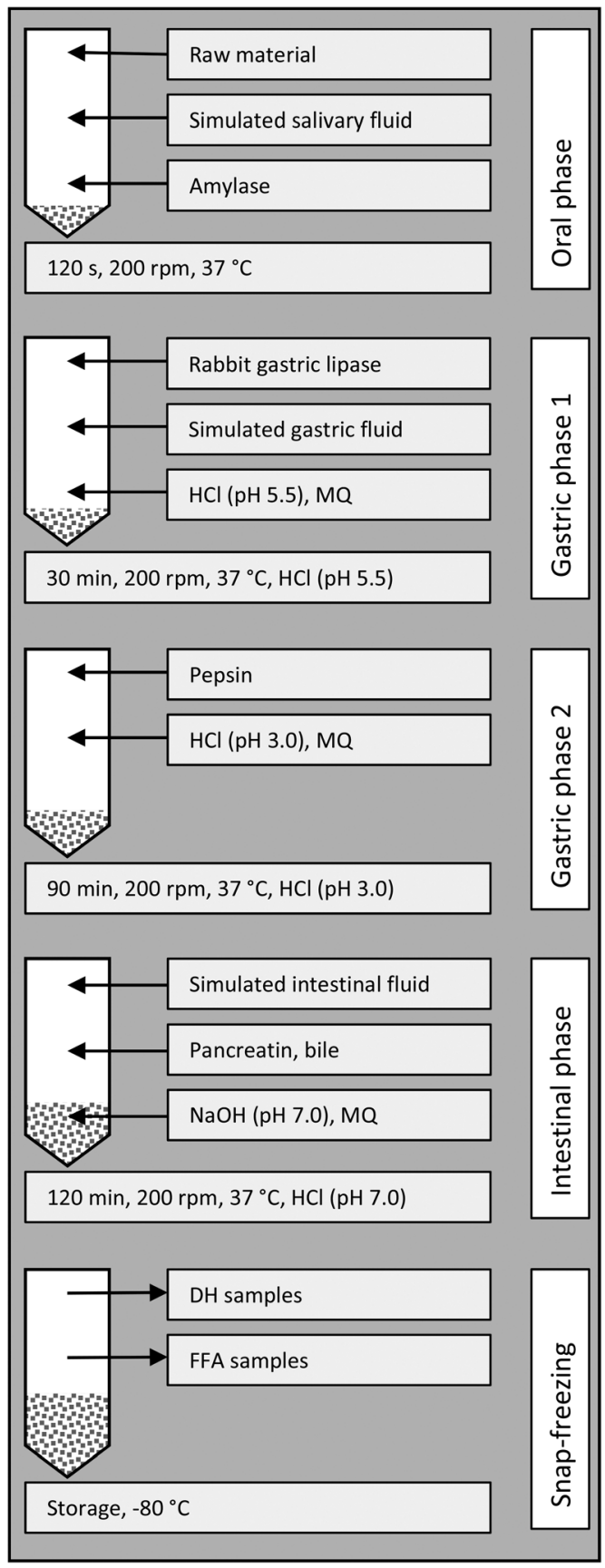

Fig. 2 Scheme for the in vitro digestion. $M Q=$ ultrapure water, $D H=$ degree of protein hydrolysis, and FFA = liberated (free) fatty acids. by drying at $105{ }^{\circ} \mathrm{C}$, overnight; the protein content was measured according to Slocombe et al. (2013); ${ }^{20}$ total fatty acids and proportions of individual fatty acids were measured according to Cavonius et al. (2014); ${ }^{21}$ carbohydrates were measured according to Herbert et al. (1971), ${ }^{22}$ using a scaleddown method adapted for 96-well plates; and the ash content was determined by heating to $550^{\circ} \mathrm{C}$ for $3 \mathrm{~h}$.

\section{Analysis of the degree of protein hydrolysis (DH)}

For the present study, we define protein accessibility as the amount of peptide bonds cleaved in the in vitro digestion model. The DH was based on the method reported by AdlerNissen, $1979,{ }^{23}$ in which primary amines are detected, with the following adjustments: (i) after inactivating enzymes at $75{ }^{\circ} \mathrm{C}$ in $1 \% \mathrm{w} / \mathrm{v}$ sodium dodecyl sulphate $(\geq 98.5 \%$ pure, dissolved in ultrapure water), samples were stored at $-80{ }^{\circ} \mathrm{C}$ awaiting further analysis; (ii) after thawing, samples were centrifuged $(2000 \mathrm{~g}, 5 \mathrm{~min})$ to remove light-scattering particles; (iii) spectrophotometric analysis was adapted to a 48-well plate (Costar 3548, Corning) by scaling down all volumes by a factor of 10; and (iv) the amount of broken peptide bonds was measured at $420 \mathrm{~nm}$ where there is little absorption by the polystyrene 48-well plate (instead of at $340 \mathrm{~nm}$ ). Plate-readers used were a Tecan Safire 2 plate reader with Magellan software version 5.03 and a FluoSTAR Omega (BMG Labtech) with Omega software version 1.30. Samples were analysed in triplicate. Leucine (Sigma, purity $\geq 98 \%$ ) was used as a standard (0-7.5 mM). The DH was expressed as $h / h_{\text {tot }} \times 100$, where $h$ is the sample's amount of broken peptide bonds after subtracting the digested SW-blank, and $h_{\text {tot }}$ is the maximum amount of peptide bonds in any given sample. Values for $h_{\text {tot }}$, see Table 2, were calculated from the amino acid profiles of Nannochloropsis as reported previously from work on the same material, ${ }^{3}$ while the $h_{\text {tot }}$-value for casein was calculated as suggested by Babault et al., 2014. ${ }^{24}$

\section{Analysis of total and liberated fatty acids}

For the present study, we define lipid accessibility as the amount of FFAs liberated from their parent molecule in the in vitro digestion model. The total fatty acids (TFAs, i.e. all fatty acids, regardless if esterified or not) were quantified in all materials prior to digestion using direct transesterification according to Cavonius et al. (methanolic-HCl method); ${ }^{21}$ we previously have shown this method to recover fatty acids more

Table 1 Composition of $\mathrm{pH}$-shift processed Nannochloropsis, used in in vitro digestion as published previously; ${ }^{3}$ values in parentheses indicate the range (max-min, i.e. the difference between the largest and smallest value, since the number of replicates is typically small: $n=2$, in many cases)

\begin{tabular}{lllll}
\hline $\begin{array}{l}\text { Material (pH-shifted } \\
\text { Nannochloropsis) }\end{array}$ & $\begin{array}{l}\text { Dry/wet } \\
\text { mass (\%) }\end{array}$ & $\begin{array}{l}\text { Protein/dry } \\
\text { mass (\%) }\end{array}$ & $\begin{array}{l}\text { Total fatty acids/ } \\
\text { dry mass }{ }^{a}(\%)\end{array}$ & $\begin{array}{l}\text { Carbohydrate/ } \\
\text { dry mass (\%) }\end{array}$ \\
\hline LYS & $10(0.5)$ & $19(0.7)$ & $11(0.2)$ & $37(3.3)$ \\
P(7) & $13(3.3)$ & $23(1.4)$ & $12(1.5)$ & $42(4.5)$ \\
P(10) & $13(2.2)$ & $24(3.0)$ & $13(0.5)$ & $58(4.6)$
\end{tabular}

${ }^{a}$ Fatty acid profile of all algae-containing samples was similar in all cases, with a mean composition of $34 \%$ saturated fatty acids, $38 \%$ monounsaturated fatty acids and $27 \%$ PUFAs. 
Table $2 h_{\text {tot }}$-Values, the maximum theoretical amount of peptide bonds in a sample for the various digested materials calculated from data according to Babault et al. ${ }^{24}$ and Cavonius et al. ${ }^{3}$

\begin{tabular}{ll}
\hline Sample & $h_{\text {tot }}$ Value $\left(\mathrm{mmol} \mathrm{l}^{-1}\right)$ \\
\hline CAS & 220 \\
ALG & Assumed to be as LYS \\
LYS & 189 \\
$\mathrm{P}(7)$ & 257 \\
$\mathrm{P}(10)$ & 317 \\
$\mathrm{P}(7) \mathrm{H}$ & Assumed to be as $\mathrm{P}(7)$ \\
$\mathrm{P}(10) \mathrm{H}$ & Assumed to be as $\mathrm{P}(10)$ \\
$\mathrm{P}(7) \mathrm{NF}$ & Assumed to be as $\mathrm{P}(7)$
\end{tabular}

completely than the Bligh and Dyer extraction, however, it does not distinguish between esterified fatty acids and FFAs. ${ }^{21}$ The determination of FFAs liberated during digestion was based on the Bligh and Dyer lipid extraction method ${ }^{25}$ followed by separation of lipid classes by solid phase extraction (SPE) according to Balasubramanian et al., 2013. ${ }^{26}$ Some minor modifications were applied to the Bligh and Dyer extraction as follows: the extraction was carried out on ice, with all solvents ice-cold. To each digested sample of $1.5 \mathrm{ml}, 1.0 \mathrm{mg}$ internal standard (nonadecanoic acid, C19:0, from Larodan in Solna, Sweden, purity $\geq 99 \%$, in $200 \mu$ l chloroform) was added. Chloroform-methanol (chloroform: Sigma-Aldrich, purity $\geq 99.8 \%$; methanol: Fluka, purity $\geq 99.9 \%$ ) with $0.05 \%$ $\mathrm{w} / \mathrm{v}$ butylated hydroxytoluene (BHT from Fluka, purity $\geq 99.0 \%$ ), $4.5 \mathrm{ml}$, was added and the tubes were vortexed for $60 \mathrm{~s}$. Chloroform, $1.5 \mathrm{ml}$, was then added and the tubes were vortexed for $15 \mathrm{~s}$, where after $1.5 \mathrm{ml}$ of aqueous $\mathrm{NaCl}(0.5 \%$ $\mathrm{w} / \mathrm{v}$ ) was added and the tubes were vortexed for $30 \mathrm{~s}$. Phaseseparation was aided by centrifugation $\left(2000 g, 4{ }^{\circ} \mathrm{C}, 6 \mathrm{~min}\right)$. The organic phase was transferred to a clean tube and the remaining aqueous phase was re-extracted with $3.0 \mathrm{ml}$ chloroform, followed by $30 \mathrm{~s}$ vortexing and centrifugation as above, before pooling the organic phases. The solvent was evaporated under $\mathrm{N}_{2(\mathrm{~g})}$ at $40{ }^{\circ} \mathrm{C}$ and re-dissolved in $0.5 \mathrm{ml}$ chloroform.

Lipid classes (neutral lipids, FFAs and polar lipids) were separated by SPE according to the report of Balasubramanian et al., $2013^{26}$ which was in turn based on the report of Kaluzny et al., $1985 ;{ }^{27}$ we confirmed that fatty acids eluted in the appropriate fraction by studying the recovery of C21:0 eluted according to the method and found the yield to be close to $100 \%$. Solvents used were hexane (Sigma, purity $\geq 97.0 \%$ ), chloroform (as above), 2-propanol (Fisher, purity $=99.98 \%$ ), diethyl ether (Sigma, purity $\geq 99.8 \%$ ), glacial acetic acid (Scharlau, purity $\geq 99.8 \%$ ), and methanol as above. The fraction containing FFAs was collected and the solvent was evaporated under $\mathrm{N}_{2(\mathrm{~g})}$ at $40{ }^{\circ} \mathrm{C}$ and re-dissolved in toluene (Scharlau, purity $\geq 99.8 \%$ ) while awaiting fatty acid quantification. FFAs were converted into fatty acid methyl esters and quantified by the method according to Cavonius et al., 2014, as above. ${ }^{21}$ FFAs liberated from the parent molecule during digestion are expressed as $\left(\mathrm{FFA}-\mathrm{FFA}_{\mathrm{SW}}\right) / \mathrm{TFA} \times 100$, where $\mathrm{FFA}_{\mathrm{SW}}$ are the fatty acids liberated in the digested SW control; the same calculation was applied to individual fatty acids.

\section{Statistical analysis}

To produce all samples, the $\mathrm{pH}$-shift process was performed on two separate days with $\mathrm{P}(7)$ produced on either days $(n=2)$ used to assess the reproducibility of the $\mathrm{pH}$-shift process. Analysis of DH, FFAs and TFAs on non-digested samples was carried out in triplicate with the means being reported without variance. Digestions were performed in triplicate on each type of sample. Analysis of DH and FFAs on digested samples was carried out once for each digestate $(n=3)$.

Results from the two separate days of $\mathrm{P}(7)$ were compared by the $T$-test (independent samples, two-tailed, 95\% confidence interval) and analytical data were pooled once it was confirmed that there was no significant difference between production days for either DH or FFAs. The DH and FFAs after digestion in different materials were compared by one-way ANOVA, with both Welch and Brown-Forsythe tests since the data are heteroscedastic, followed by a Games-Howell post-hoc test; $p<0.05$ was considered statistically significant.

\section{Results and discussion}

\section{Degree of protein hydrolysis (DH) in in vitro digestion}

After digestion, $32-50 \%$ of the peptide bonds had been hydrolysed in the samples containing algae, which was comparable with the CAS control in which $40 \%$ of the bonds had been hydrolysed, see Fig. 4. There was no significant difference in $\mathrm{DH}$ between digested $\mathrm{P}(7)$-samples from $\mathrm{pH}$-shift processes performed on two separate days, indicating that the $\mathrm{pH}$-shift process is reproducible. The data of the two separate $\mathrm{P}(7)$ samples are therefore pooled in Fig. 3. However, in the ALG sample (i.e. whole algae), only $3 \%$ of the peptide bonds were hydrolysed, a significant difference from most other types of materials [i.e. $p \leq 0.033$ for $\mathrm{P}(7), \mathrm{P}(10), \mathrm{P}(7) \mathrm{H}, \mathrm{P}(7) \mathrm{NF}$ ]. The only other significant difference regarding $\mathrm{DH}$ was between $\mathrm{P}(7)$ and $\mathrm{P}(7) \mathrm{NF}(p=0.004)$, with the lowest $\mathrm{DH}$ for any of the $\mathrm{pH}$-shift products detected in $\mathrm{P}(7) \mathrm{NF}$ at $32 \%$. A large variance was noted for LYS samples, where two of the replicates were within the range of the $\mathrm{pH}$-shift process-products, while the third was just slightly higher than the ALG sample; analyses were repeated several times to confirm this result. Due to this large variance, there is no statistical significance between the key materials LYS (coefficient of variation $=59 \%$ ) on the one hand and products of the pH-shift process (coefficient of variation $=10-26 \%$ ) on the other hand, even if mean values differ. Differences between heat-treated and non-heated materials were small for both $\mathrm{P}(7)$ and $\mathrm{P}(10)$, suggesting that the heattreatment had neither a positive nor a negative impact on $\mathrm{DH}$. Thus, the results strongly indicate that disruption of the Nannochloropsis cells is necessary to make the proteins accessible to the digestive enzymes.

Prior to digestion, primary amines corresponding to approximately $7 \%$ of all peptide bonds were detected in the algae-containing samples. If the variance of analysis is taken into account, there was no significant difference between any of the algae-containing starting materials. Neither was there 


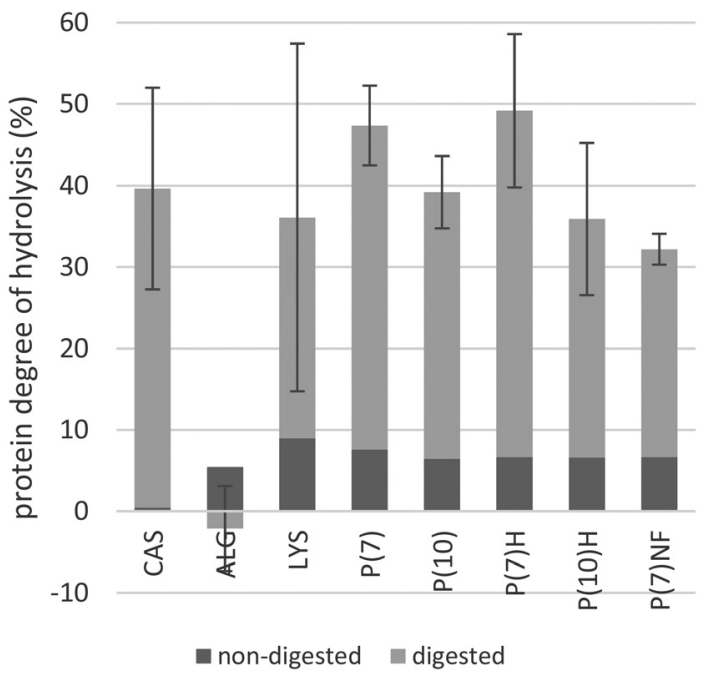

Fig. 3 Degree of protein hydrolysis for non-digested (dark grey) and digested material; $n=1$ for non-digested, $n=3$ for digested material except for $\mathrm{P}(7)$, where the number of samples is doubled in both cases (error bars show standard deviation). Explanation of abbreviations: CAS = casein in seawater; $A L G=$ whole algae in seawater; $L Y S=$ broken algae in seawater; $\mathrm{P}(7)$ and $\mathrm{P}(10)=$ product of the $\mathrm{pH}$-shift process with solubilisation at either $\mathrm{pH} 7$ or $\mathrm{pH} 10 ; \mathrm{P}(7) \mathrm{H}$ and $\mathrm{P}(10) \mathrm{H}=$ heat-treated product of the $\mathrm{pH}$-shift process at respective $\mathrm{pH} ; \mathrm{P}(7) \mathrm{NF}=$ non-frozen product.

any indication that $\mathrm{DH}$ increased with an increased $\mathrm{pH}$-shift processing time (e.g. by endogenous proteolytic enzymes of the algae), though it cannot be ruled out that the $c a .7 \%$ of initial DH is caused by algal proteases, acting during the harvest, handling and storage of the algal raw material. However, microalgae are reported to contain non-protein nitrogen in the form of nucleic acids, amines, glucosamides, cell wall material, pigments and even free amino acids and inorganic nitrogen; ${ }^{2,28}$ some of these species could contribute towards the primary amines detected prior to digestion. ${ }^{23}$

CAS was included as a reference protein, since it is known to have high digestibility, i.e. $93 \% .^{29}$ In the present study, digested CAS had a DH of $40 \%$. For comparison, a different study applying the Infogest in vitro digestion mode ${ }^{15}$ reported a DH of $80-84 \%$ for goat milk and kefir. ${ }^{30}$ A similar study on the digestibility of fish protein isolate used a different in vitro digestion method, but the same batch of casein, and reported a DH of $15 \%$ for the casein control. ${ }^{31}$ In the present study, we observed that the casein powder remained in small particles and did not dissolve properly, thus, the large difference in DH between pure casein and milk/kefir may be attributed to a smaller surface area available to the digestive enzymes in pure casein, compared to casein present in its native state in milk.

For the heat treatment, $72{ }^{\circ} \mathrm{C}$ for $15 \mathrm{~s}$ was chosen, a temperature and time sufficient to kill spoilage micro-organisms in milk. ${ }^{19}$ The heat-treated $\mathrm{pH}$-shift process products did not differ significantly from the non-heated products, suggesting that the heat-treatment has neither a detrimental nor a beneficial effect on the accessibility of $N$. oculata protein. Our finding agrees with that of Hori et al. (1990), in which the cyanobacterium Nostoc commune was investigated and it likewise was reported that heat treatment had little effect on the in vitro protein digestibility. ${ }^{8}$

Comparison of frozen and non-frozen $\mathrm{pH}$-shift process products, i.e. $\mathrm{P}(7)$ and $\mathrm{P}(7) \mathrm{NF}$ was included to assess the impact of freezing on the digestibility of lipids and proteins. Although it may be possible to process microalgae into fresh food or feed for immediate consumption, such an approach was impractical for the study design: storing $\mathrm{pH}$-shift process products, at e.g. $4{ }^{\circ} \mathrm{C}$, over the two weeks it took to perform the in vitro digestions may have altered the composition of the product and further increased the variance. Alternatively, in an industrial food-processing setting, microalgae could be processed and stored frozen prior to consumption. When comparing $\mathrm{P}(7)$ and $\mathrm{P}(7) \mathrm{NF}$, these two were found to be significantly different, suggesting that freezing improves the accessibility of $N$. oculata proteins slightly. Cold-induced denaturation of proteins can occur, particularly when proteins are stabilised primarily by non-polar interactions. ${ }^{18}$ Indeed, our previous experience of $N$. oculata proteins ${ }^{3}$ has given us reason to believe that much of the protein is embedded in membranes. To perform SDS-PAGE, Laemmli buffer needed to be augmented with SDS and urea to denature the proteins, indicative of non-polar interactions. ${ }^{3}$ Thus, while results indicate that freezing increases the accessibility of $N$. oculata proteins in $\mathrm{P}(7)$, future investigations could see if the same holds true for $\mathrm{P}(7) \mathrm{H}, \mathrm{P}(10)$ and $\mathrm{P}(10) \mathrm{H}$.

\section{Liberated FFAs in in vitro digestion}

After digestion, $34-55 \%$ of the total fatty acids had been liberated in most of the algae-containing materials, with the exception of the ALG sample, where less FFAs were detected than in the SW blank, resulting in a negative value. The difference between ALG and other samples was highly significant ( $p \leq$ $0.007)$. There was no significant difference in the amounts of FFA present after digestion between $\mathrm{P}(7)$-samples from two separate $\mathrm{pH}$-shift processes; the results are therefore pooled in Fig. 4 . Thus, the results strongly indicate that disruption of the Nannochloropsis cells is necessary also to make the lipids accessible to the digestive enzymes.

Among the pH-shift processed algae, significantly less FFAs were liberated during the in vitro digestion of the LYS sample (34\%) than in the $\mathrm{P}(7), \mathrm{P}(10)$ and $\mathrm{P}(10) \mathrm{H}$ samples $(44-49 \%, p \leq$ $0.049)$. When a $T$-test was applied to the pooled data of $\mathrm{pH}^{-}$ shift process-products carried out at $\mathrm{pH} 7$ and compared to products of the $\mathrm{pH}$ 10-process, differences were also highly significant $(p=0.001)$ with the latter showing a higher degree of lipolysis. Indeed, the highest fraction of FFAs liberated by the in vitro digestion model was $52 \%$ in $\mathrm{P}(10) \mathrm{H}$, closely followed by $\mathrm{P}(10)$ and $\mathrm{P}(7)$ at $49 \%$ and $46 \%$, respectively. These values are comparable to those reported by Lin et al. (2014), in a study that subjected emulsified and non-emulsified algal oil to an in vitro digestion model including gastric lipase. ${ }^{32}$ Thus, the results further demonstrate that subsequent $\mathrm{pH}$-shift processing can improve lipolysis, which may be due to a confor- 


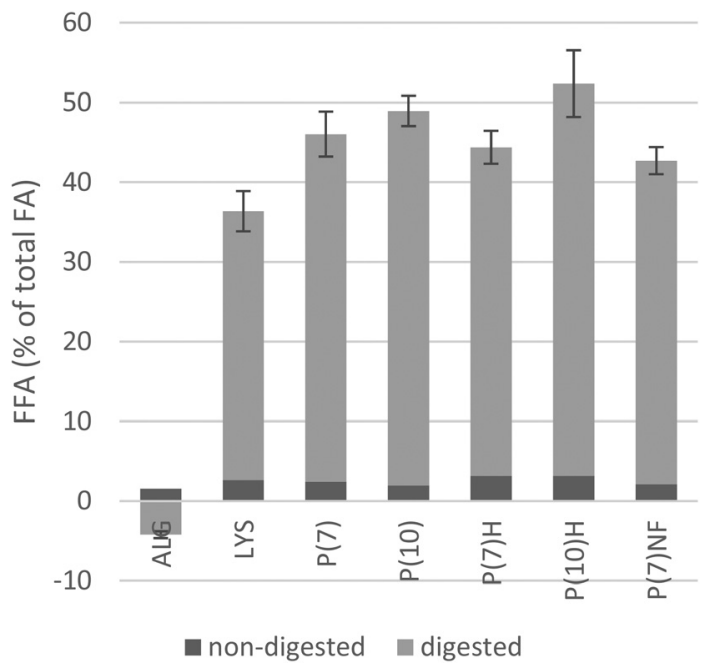

Fig. 4 Percentage of FFAs for non-digested (dark grey) and digested material (grey), relative to the total fatty acids present in the various materials; the negative control has been subtracted from the FFA sum; $n=1$ for non-digested, $n=3$ for digested material except for $\mathrm{P}(7)$, where the number of samples is double in both cases (error bars show standard deviation). $A L G=$ whole algae in seawater; $L Y S=$ broken algae in seawater; $\mathrm{P}(7)$ and $\mathrm{P}(10)=$ product of the $\mathrm{pH}$-shift process with solubilisation at either $\mathrm{pH} 7$ or $\mathrm{pH} 10 ; \mathrm{P}(7) \mathrm{H}$ and $\mathrm{P}(10) \mathrm{H}=$ pasteurised product of the $\mathrm{pH}$-shift process at respective $\mathrm{pH} ; \mathrm{P}(7) \mathrm{NF}=$ non-frozen product.

mational change of protein-lipid complexes, resulting in better access by lipases.

Prior to digestion, small amounts of FFAs were detected in all algae-containing materials, corresponding to $2-3 \%$ of the TFAs. Possibly, the FFAs present before digestion were a result of endogenous algal lipases, acting during the harvest, handling and storage of the algal raw material. It is well-established that in both plant and animal food raw materials, there is considerable post-harvest hydrolysis of fatty acids attached to phospholipids and for vegetable material also to glycolipids. ${ }^{33,34}$ While the study of post-harvest lipolysis of microalgal lipids is worth dedicating future investigations to, for this study it is enough to note that there was no statistically significant difference in initial FFAs between analysis replicates of the various algae-containing raw materials. However, the presence of FFAs during digestion is known to inhibit lipases in in vitro digestion. ${ }^{16}$ In vivo, FFAs are removed when they are absorbed by enterocytes, whereas in the static model employed here, some product inhibition may occur. Product inhibition may in part explain why not all fatty acids were released, a maximum release of $52 \%$ was determined.

In the current study, only liberation of FFAs was studied as an index for lipid accessibility. Since monoacylglycerides are known to be absorbed in the small intestine, our results on FFA-liberation are not fully equivalent to lipid accessibility, but nonetheless provide an indication. In the limited number of studies available on in vitro algal lipid digestibility, FFAs have been used in the past as a measure of lipid accessibility. ${ }^{32}$

The separation of FFAs from other lipid classes relied on SPE. However, after performing SPE on the non-digested SW blank, a material which initially contained no other fatty acid apart from the internal standard, palmitic and stearic acids were detected. Therefore, the contamination must be expected to also be present in the algae-containing materials. The amount of palmitic and stearic acids was small relative to the total amount of liberated FFAs of the digested algae-containing materials $(<3 \%)$ and therefore considered negligible in the context of total liberated FFAs. However, when analysing individual fatty acids liberated during digestion relative to the corresponding individual fatty acids present in the nondigested initial material (in the esterified form), the contamination had a major impact: especially for stearic acid, which is present in very low amounts in Nannochloropsis, the relative increase following digestion was unreasonably high (up to $290 \%$ increase). According to Notter et al. (2008), who reported the same contamination, palmitic and stearic acids originate from the polypropylene in the commercial SPE-columns used. $^{35}$

By considering the profile of individual fatty acids, it was seen that a small contamination of palmitic acid and stearic acid was present in the non-digested SW blank, therefore, differences in the liberation of palmitic and stearic acids were not considered further. More than $70 \%$ of the total palmitoleic (C16:1 n7) and oleic acid (C18:1 n9) was released in $\mathrm{P}(7), \mathrm{P}(10)$, $\mathrm{P}(7) \mathrm{H}$, and $\mathrm{P}(10) \mathrm{H}$, with less of these fatty acids released from $\mathrm{P}(7) \mathrm{NF}$, LYS and ALG, following the same pattern as for total liberated fatty acids (above). 50\% or more lauric acid (C12:0) and myristic acid (C14:0) was released in $\mathrm{P}(7), \mathrm{P}(10), \mathrm{P}(7) \mathrm{H}$, and $\mathrm{P}(10) \mathrm{H}$. Only $2-3 \%$ of total eicosapentaenoic acid (C20:5 n3) was detected as liberated FFA in products of the pH-shift process after digestion, with none detected in LYS and ALGsamples. More liberated arachidonic acid (C20:4 n6) was detected in the digested SW and CAS-blanks than in any of the algae-containing materials. Since PUFAs are sensitive to oxidation (also during in vitro digestion ${ }^{36}$ ) it is possible that C20:5 n3 and C20:4 n6 were degraded and therefore could not be detected as such. An alternative explanation is that the PUFAs were not released to the same degree as the more saturated fatty acids: Ryckebosch et al. (2014) have shown that in a study of Nannochloropsis oculata containing ca. $30 \%$ lipid per dry weight, only $68 \%$ of the C20:5 n3 was located in the glycolipids. ${ }^{37}$ Further studies could investigate the position of the eicosapentaenoic acid in Nannochloropsis glycolipids and to which degree the eicosapentaenoic acid is accessible to human digestive enzymes.

Although we demonstrated that lipolysis can be slightly increased by applying the $\mathrm{pH}$-shift process, it is less clear whether the $\mathrm{pH}$-shift processing changes the protein accessibility. It could thus be asked if $\mathrm{pH}$-shift-processing beyond the disruption step is justified from a nutritional point of view: the addition of an acid and base, as well as equipment and time needed for the $\mathrm{pH}$-shift process represent significant investments, but resulted in only a modest increase in fatty acid accessibility. Nonetheless, it is possible that the full $\mathrm{pH}$ shift process imparts other advantages on the final product. For example, improved protein functionality has been reported 
after $\mathrm{pH}$-shift processing of fish ${ }^{38}$ and is worth exploring for algae-containing materials.

In summary, the most striking feature of the results presented here is the low accessibility of the ALG material, both in terms of DH and liberated FFAs. The low accessibility of whole cells is not surprising in light of previous studies on the cell wall structure of Nannochloropsis: it has been reported that the Nannochloropsis cell wall is composed of cellulose, protected by an outer layer of algaenan. ${ }^{14}$ Therefore, whole algal cells can be expected to pass through the human digestive tract largely unaffected, since humans lack the enzymes needed to hydrolyse the cellulosic cell wall. Given that the detected $\mathrm{DH}$ and liberated FFAs in digested ALG were lower than those detected in the digested SW-control, it can even be speculated that the whole cells adsorb and bind digestive enzymes, acting as anti-nutrients. ${ }^{11,13,39,40}$ In a rat feeding trial, some animals fed $50 \mathrm{mg}$ whole Nannochloropsis daily for eight weeks developed intestinal atrophy and transmural necrosis not observed in the control group, suggesting that whole algae challenged the rats' gastrointestinal tract to the point of injury. ${ }^{41}$ It has thus been confirmed that it is necessary to disrupt the cell wall of Nannochloropsis to make the proteins and lipids accessible, in agreement with earlier studies. ${ }^{2,6}$

\section{Conclusion}

The present study demonstrates that cell disruption is necessary to make Nannochloropsis proteins and lipids accessible to mammalian digestive enzymes used in the applied in vitro digestion model. By processing the algal material with the pH-shift method beyond the initial disruption step, it was further demonstrated that fatty acid liberation could be modestly increased. With good accessibility (>50\%) of amino acids and TFAs, pH-shift processed Nannochloropsis has potential as a functional food or feed ingredient. Future studies should investigate the fate of the PUFAs during digestion.

\section{Abbreviations}

ALG Whole algae in seawater

CAS Casein

$\mathrm{DH} \quad$ Degree of protein hydrolysis

FFA Free fatty acid

LYS Lysate

$h \quad$ The amount of broken peptide bonds of a sample after subtracting the seawater-blank

$h_{\text {tot }} \quad$ The maximum theoretical amount of peptide bonds in a sample

$\mathrm{P}(7) \quad$ Product of the $\mathrm{pH}$-shift process with solubilisation at $\mathrm{pH} 7$

$\mathrm{P}(7) \mathrm{H} \quad$ Product of the $\mathrm{pH}$-shift process with solubilisation at pH 7, heat-treated
$\mathrm{P}(7) \mathrm{NF}$ Product of the $\mathrm{pH}$-shift process with solubilisation at pH 7, non-frozen

$\mathrm{P}(10) \quad$ Product of the $\mathrm{pH}$-shift process with solubilisation at pH 10

$\mathrm{P}(10) \mathrm{H}$ Product of the $\mathrm{pH}$-shift process with solubilisation at pH 10, heat-treated

PUFA Polyunsaturated fatty acid

SDS Sodium dodecyl sulphate

SPE Solid phase extraction

SW Seawater

TFA Total fatty acid

\section{Acknowledgements}

This study was funded by Chalmers University of Technology. We would like to thank the following people for contributing to the study: Cecilia Tullberg, Marie Alminger, Annette Almgren, Charlotte Egger, Cecilia Svelander, Hanna Harrysson, Nikul Soni, Otto Savolainen, Niklas Engström, Cyrielle Bonzom, Nils-Gunnar Carlsson, and Rita Cavonius.

\section{References}

1 M. Vanthoor-Koopmans, R. H. Wijffels, M. J. Barbosa and M. H. M. Eppink, Bioresour. Technol., 2013, 135, 142-149.

2 W. E. Becker, in Handbook of Microalgal Culture: Applied Phycology and Biotechnology, ed. Q. Hu and A. Richmond, John Wiley \& Sons, Somerset, NJ, USA, 2nd edn, 2013.

3 L. R. Cavonius, E. Albers and I. Undeland, Algal Res., 2015, 11, 95-102.

4 S. K. Marmon, A. Krona, M. Langton and I. Undeland, J. Agric. Food Chem., 2012, 60, 7965-7972.

5 Q. Liu, R. Geng, J. Y. Zhao, Q. Chen and B. H. Kong, J. Agric. Food Chem., 2015, 63, 4853-4861.

6 G. Hedenskog, L. Enebo, J. Vendlova and B. Prokes, Biotechnol. Bioeng., 1969, 11, 37-51.

7 M. A. Devi, G. Subbulakshmi, K. M. Devi and L. V. Venkataraman, J. Agric. Food Chem., 1981, 29, 522525.

8 K. Hori, T. Ueno-Mohri, T. Okita and G. Ishibashi, Plant Foods Hum. Nutr., 1990, 40, 223-229.

9 H. J. Morris, A. Almarales, O. Carrillo and R. C. Bermudez, Bioresour. Technol., 2008, 99, 7723-7729.

10 G. Graziani, S. Schiavo, M. A. Nicolai, S. Buono, V. Fogliano, G. Pinto and A. Pollio, Food Funct., 2013, 4, 144-152.

11 S. M. Tibbetts, J. E. Milley and S. P. Lall, J. Appl. Phycol., 2015, 27, 1109-1119.

12 L. P. Goh, S. P. Loh, M. Y. Fatimah and K. Perumal, Malaysian J. Nutr., 2009, 15, 77-86.

13 A. Skrede, L. T. Mydland, O. Ahlstrom, K. I. Reitan, H. R. Gislerod and M. Overland, J. Anim. Feed Sci., 2011, 20, 131-142. 
14 M. J. Scholz, T. L. Weiss, R. E. Jinkerson, J. Jing, R. Roth, U. Goodenough, M. C. Posewitz and H. G. Gerken, Eukaryotic Cell, 2014, 13, 1450-1464.

15 M. Minekus, M. Alminger, P. Alvito, S. Ballance, T. Bohn, C. Bourlieu, F. Carriere, R. Boutrou, M. Corredig, D. Dupont, C. Dufour, L. Egger, M. Golding, S. Karakaya, B. Kirkhus, S. Le Feunteun, U. Lesmes, A. Macierzanka, A. Mackie, S. Marze, D. J. McClements, O. Menard, I. Recio, C. N. Santos, R. P. Singh, G. E. Vegarud, M. S. J. Wickham, W. Weitschies and A. Brodkorb, Food Funct., 2014, 5, 11131124.

16 J. C. B. N'Goma, S. Amara, K. Dridi, V. Jannin and F. Carrière, Ther. Delivery, 2012, 3, 105-124.

17 P. Capolino, C. Guérin, J. Paume, J. Giallo, J. M. Ballester, J. F. Cavalier and F. Carrière, Food Dig., 2011, 2, 43-51.

18 Food Chemistry, ed. O. R. Fennema, CRC Press, Boca Raton, 1996.

19 P. J. Fellows, Food Processing Technology, Woodhead Publishing Limited, Cambridge, England, 2nd edn, 2000.

20 S. P. Slocombe, M. Ross, N. Thomas, S. McNeill and M. S. Stanley, Bioresour. Technol., 2013, 129, 51-57.

21 L. R. Cavonius, N. G. Carlsson and I. Undeland, Anal. Bioanal. Chem., 2014, 406, 7313-7322.

22 D. Herbert, P. J. Phipps and R. E. Strange, in Methods in Microbiology, ed. J. R. Norris and D. W. Ribbons, Academic Press Inc., London, 1971, vol. 5B, (ch. 3), pp. 210-383.

23 J. Adler-Nissen, J. Agric. Food Chem., 1979, 27, 1256-1262.

24 N. Babault, G. Deley, P. Le Ruyet, F. Morgan and F. A. Allaert, J. Int. Soc. Sports Nutr., 2014, 11, 36-45.

25 E. G. Bligh and W. J. Dyer, Can. J. Biochem. Physiol., 1959, 37, 911-917.

26 R. K. Balasubramanian, T. T. Y. Doan and J. P. Obbard, Chem. Eng. J., 2013, 215, 929-936.
27 M. A. Kaluzny, L. A. Duncan, M. V. Merritt and D. E. Epps, J. Lipid Res., 1985, 26, 135-140.

28 E. Barbarino and S. Lourenço, J. Appl. Phycol., 2005, 17, 447-460.

29 J. Boye, R. Wijesinha-Bettoni and B. Burlingame, Br.J. Nutr., 2012, 108(Suppl 2), S183-S211.

30 S. Nehir El, S. Karakaya, S. Simsek, D. Dupont, E. Menfaatli and A. T. Eker, Food Funct., 2015, 6, 2322-2330.

31 S. K. Marmon and I. Undeland, Food Chem., 2013, 138, 214-219.

32 X. Lin, Q. Wang, W. Li and A. J. Wright, Food Funct., 2014, 5, 2913-2921.

33 M. J. Kim, J. M. Oh, S. H. Cheon, T. K. Cheong, S. H. Lee, E. O. Choi, H. G. Lee, C. S. Park and K. H. Park, J. Agric. Food Chem., 2001, 49, 2241-2248.

34 H. A. Roldán, S. I. Roura, C. L. Montecchia, O. Pérez Borla and M. Crupkin, J. Food Biochem., 2005, 29, 187-204.

35 S. J. Notter, B. H. Stuart, B. B. Dent and J. Keegan, Eur. J. Lipid Sci. Technol., 2008, 110, 73-80.

36 K. Larsson, L. Cavonius, M. Alminger and I. Undeland, J. Agric. Food Chem., 2012, 60, 7556-7564.

37 E. Ryckebosch, C. Bruneel, R. Termote-Verhalle, K. Goiris, K. Muylaert and I. Foubert, Food Chem., 2014, 160, 393400.

38 S. K. Marmon and I. Undeland, J. Agric. Food Chem., 2010, 58, 10480-10486.

39 O. Marrion, J. Fleurence, A. Schwertz, J. L. Gueant, L. Mamelouk, J. Ksouri and C. Villaume, J. Appl. Phycol., 2005, 17, 99-102.

40 E. Rodríguez De Marco, M. E. Steffolani, C. S. Martínez and A. E. León, LWT-Food Sci. Technol., 2014, 58, 102-108.

41 K. Nuño, A. Villarruel-López, A. M. Puebla-Pérez, E. Romero-Velarde, A. G. Puebla-Mora and F. Ascencio, J. Funct. Foods, 2013, 5, 106-115. 